\title{
Post Catastrophe Fallouts and Challenges to Swim to Safety (Particularly in the Post Covid-19 Impasse)
}

\author{
Devidutta Dash ${ }^{1}$, Arun Agarwal ${ }^{2}$, Kabita Agarwal $^{3}$, Gourav Misra 4 \\ 1,2 Department of ECE, ITER, Siksha O Anusandhan Deemed to be University, Bhubaneswar, Odisha, \\ India-751030, Email: ${ }^{1}$ arunagrawal@ soa.ac.in, ${ }^{2}$ dashtitanium11@gmail.com
}

${ }^{3}$ Department of Computer Science and Application, Utkal University, Vani Vihar, Bhubaneswar751004, Odisha, India, Email: akkavita22@gmail.com

${ }^{4}$ School of Electronic Engineering, Dublin City University, Glasnevin, Dublin 9, Ireland, Email: gourav.misra.ima@gmail.com

\begin{abstract}
The continuing dangers presented by the current pandemic affects the events due to the COVID-19. The economy has imploded like never before. The most advanced countries were ignorant, except for possible measures such as lockdowns and hastily imposed precautionary legislation. The entire world came to a halt and the people were suffered, businesses have been crippled and life became constrained and perplexing. Most of the people were jobless, fatal accidents, and so on. The virus made no differentiation and those who had a strong immune system and were fortunate enough to survive. Human suffering is on an unbelievable and indefinable scale. The jobless suffered in life because transportation was crippled.
\end{abstract}

Keywords: COVID-19; Pandemic; Virus; Economy; Survival; Immunity

\section{INTRODUCTION}

The earth has experienced and witnessed progress prosperity and at the same time chaos and disaster. The recorded history of the last century was reported that the world war begins in 1914 and ends in 1918 with 22 million dead. The post-world war was never better between 1918 and 1922, where the Spanish Flu killed 50 Million people. In 1929, the global economic crisis caused the stock exchange collapse, causing millions of people to unemployed, inflation increased, and uncountable hunger deaths due to famine. The world war which 
Journal of Information Technology and Digital World (2021)

Vol. 03/ No. 01

Pages: $12-17$

https://www.irojournals.com/itdw/

DOI: https://doi.org/10.36548/jitdw.2021.1.002

spanned from 1939-1945, killed 60 million people, and in the Holocaust, 6 million Jews were killed [1]. The Korean war and the Vietnam war took heavy tolls on lives causing misery to uncountable to men and women with heavy damage to the environment. A child who is born in 1990 thinks about grandparents doesn't know how difficult life is, but they have survived several wars and catastrophes. Although today, all the amenities of our new world, a new epidemic called COVID-19 were released. A lot of complaints from the people were registered due to some of the restrictions like wearing a mask, quarantine, social gathering, and so on. The basic necessities were not completely satisfied among the people like food, electricity, running water, Wi-Fi, Netflix, and etc,. None of this happened back in the day, but humanity survived and continued to enjoy life. A small shift in our attitude can produce remarkable results.

\section{THE MIRROR}

It is different from the world in which humans are living today. Corruptness is in constant rivalry with humanity. There are people who fish out of troubled streams. But there are also people who risk their lives to save lives.

\section{THE REALITY: FACTS \& STATISTICS}

a) To be blunt, as per the recent statistics.

b) 200+ countries have been affected.

c) $92,295,500+$ people have been infected.

d) $1,977,500+$ many people have fallen prey to the deadly virus.

e) But at the same time, there are $66,000,000+$ many people who have recovered.

The Indian economy has nosedived. A similar situation in the global economy can be compared. The GDP, both at the national and global levels, has reached an all-time low in recent memory. Human capital has been seriously impacted. However, there are some silver linings. Governments have taken various measures. The contamination was attempted to be contained through legislation and all branches of government. NGOs have done remarkable work in restoring people's happiness and long-lasting pain. Entrepreneurs have done remarkable jobs in extending their support to government initiatives. More than that, some individuals stand out as liberators of people in misery $[3,4]$. 
Journal of Information Technology and Digital World (2021)

Vol. 03/ No. 01

Pages: $12-17$

https://www.irojournals.com/itdw/

DOI: https://doi.org/10.36548/jitdw.2021.1.002

\section{DRAWBACKS}

It took some time for the supply chain to return to perfection. Despite their best efforts and intentions, daily wagers working in remote locations stepped thousands of miles to save their lives. Distress and frustration became the large number of people. Nothing was spared from the pandemic's invasion, from small-scale to large-scale industries. Suffering has a long history, but humanity has always prevailed. Humans have always persevered in the face of adversity [1].

\section{CHALLENGES TO SWIM TO SAFETY}

i. People of this country have shown character, guts, resilience, integrity, and nationalism to follow the rules.

ii. The Indian economy loaded in funds to sustain and encompass the situation. And thereby, the country demonstrated ability to overcome like a phoenix.

iii. Despite the terrifying challenges, the government, institutions, NGOs, entrepreneurs, and individuals led the movement, and there was rule of law on the ground to withstand the assault.

iv. Who can ever forget the COVID WARRIORS! They demonstrated that, like the soldiers guarding the border territories, the COVID health workers, all of them, held the fort at the risk of their own lives.

v. Scientists had a challenge of their lifetimes. Labs were busy experimenting to invent the vaccine - the weapon to fight the unseen enemies.

vi. Morality triumphs over evil, and life has gradually returned to normal

vii. Places of mass gatherings like theatres, wedding parties, market places, commutations, restaurants, etc, are in the process of being resumed.

viii. Adversity teaches people to be resourceful. Despite the fact that travel was curtailed, webinars and video conferencing on a local to global scale served the purpose of paving the way for people to adjust to a new reality. As a result, revenues, man hours, and the environment are saved from pollution.

ix. Teachers learn to journey from Chalk \& Talk to Touch \& Teach. Students developed the habit of becoming self-learners. The hand holding spared them from becoming parasites. 
Journal of Information Technology and Digital World (2021)

Vol. 03/ No. 01

Pages: $12-17$

https://www.irojournals.com/itdw/

DOI: https://doi.org/10.36548/jitdw.2021.1.002

x. During this time, there was a new positive trend toward self-sufficiency. Many people either lost their jobs or returned home from far-away places, meticulously reflecting on how to become self-sufficient. There are numerous examples of people, educated, uneducated, skilled, unskilled, semi-skilled and daily labourers found their new independent ventures to make a living.

xi. Sorrow and disaster do not come alone. The external threats to our territory prompted the government to take proactive measures in strengthening our armed forces and building infrastructures across LOC and LAC.

xii. The biggest dividends the country received are -

i. Going local to global

ii. ATMANIRVAR BHARAT

iii. Boycotting of Chinese apps and by checkmating expansionistic nefarious design

iv. The period saw a never before foreign policy, realignments, multi-alignments, and new trade agreements

v. The world saw the role of the country which showed its might in not only bringing back the Indians stuck in foreign soils but also providing life-saving drugs to many countries.

vi. It was the time when people were taught to be Indians

vii. As a result of China's dark designs, many foreign investors have relocated from China to India.

viii. On the social front, the socioeconomic quotient increased, forcing families to learn to interact. Working from home with the goal of working from anywhere saved time, increased work culture, and increased accountability.

\section{CONCLUSION AND FUTURE SCOPE}

In the proposed work, it can be conclude that big pharma has reinforced its saviour perception. The drug controller general of India's grant of emergency use authorization to serum institute Covishield and Bharat Biotech's Covaxin marks the last regulatory hurdle before the commencement of anti-COVID vaccination in India. Opacity surrendering data from trials, fast-tracking of data scrutiny, and doubts over vaccine dosage and mutations have raised concerns. However, India is not an exception; each country takes a different approach. COVID-19 has put a halt to the environmental stress are putting on the universe. 
Journal of Information Technology and Digital World (2021)

Vol. 03/ No. 01

Pages: $12-17$

https://www.irojournals.com/itdw/

DOI: https://doi.org/10.36548/jitdw.2021.1.002

Despite the present impasse, the USA detects virus variants as it examines a record COVID toll of 3725. Genome sequencing helps nail virus spread mutation. Researchers plan to monitor sewage for COVID second wave. This will help find emerging city hotspots. COVID care increases the trust index of Indian companies, states a survey.

People's struggle for survival and growth has been going on since the prehistoric era. People have learned to weather all weathers, including cataclysmic times, tsunamis, earthquakes, famines, wars, epidemics, and pestilences. Surely, there is hope and humans will find their way. The handling of this pandemic in the future will be accomplished through IoT and AI.

\section{References}

[1] Swaminomics. Swaminathan S Anklesaria Aiyar Time of India, 2020

[2] S. Latif et al., "Leveraging Data Science to Combat COVID-19: A Comprehensive Review," in IEEE Transactions on Artificial Intelligence, vol. 1, no. 1, pp. 85-103, Aug. 2020, doi: 10.1109/TAI.2020.3020521.

[3] Q. Pham, D. C. Nguyen, T. Huynh-The, W. Hwang and P. N. Pathirana, "Artificial Intelligence (AI) and Big Data for Coronavirus (COVID-19) Pandemic: A Survey on the State-of-the-Arts," in IEEE Access, vol. 8, pp. 130820-130839, 2020, doi: 10.1109/ACCESS.2020.3009328.

[4] https://www.worldometers.info/coronavirus/

[5] Make Haste Slowly, Editorial, TOI, 2020

[6] Chidanand.Rajghatta@ timesgroup.com

[7] Corinne Le Quere, TOI

[8] TIMES NEWS NETWORK

[9] Ragu.Raman@timesgroup.com 
Journal of Information Technology and Digital World (2021)

Vol. 03/ No. 01

Pages: $12-17$

https://www.irojournals.com/itdw/

DOI: https://doi.org/10.36548/jitdw.2021.1.002

\section{Authors Biography}

\section{Author - 2 - Arun Agarwal}

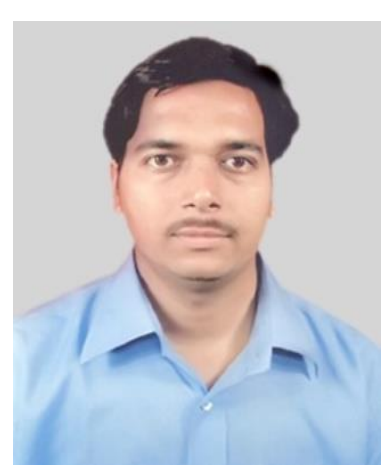

Arun Agarwal has more than 14 years of professional, research, and teaching experience in a wireless digital communication system. He is working as an Assistant Professor in the ECE department at ITER (Faculty of Engineering and Technology), Siksha 'O' Anusandhan Deemed to be University, Bhubaneswar, Odisha, India. He completed B. E (2003) in Electronics \& Telecommunication Engineering from Padmanava College of Engg., Rourkela and M. TECH (2010) in Telematics and Signal Processing from NIT, Rourkela, Odisha. Currently, he is pursuing Ph.D. from AMET University, Tamil Nadu, Chennai, India. His field of interest includes mobile wireless communication, MIMO-OFDM, LTE-A, 5G networks, and signal processing. He has over 50 research articles published in journals, national and international conferences. He is a member of IEEE \& a life member of ISTE, IETE, IACSIT, IEI professional society. He is also a member of the Editorial Board \& Reviewer of many International Journals. He has also served as a TPC of many Springer and IEEE International Conferences. 